\title{
In Vitro Starch Hydrolysis and Prediction of Glycemic Index (PGI) in "Amala" and Plantain Based Baked Products
}

\author{
Kiin-Kabari David Barine ${ }^{1}$ \& Giami Sunday Yorte ${ }^{1}$ \\ ${ }^{1}$ Department of Food Science and Technology, Rivers State Unviersity of Science and Technology, P.M.B 5080, \\ Port Harcourt, Nigeria \\ Correspondence: Kiin-Kabari, David Barine, department of Food Science and Technology, Rivers State \\ University of Science and Technology, P.M.B 5080, Port Harcourt, Nigeria. Tel: 234-803-7757473. E-mail: \\ kabaridavid@yahoo.com
}

Received: January 16, 2016 Accepted: February 16, 2016 Online Published: March 24, 2016

doi:10.5539/jfr.v5n2p73

URL: http://dx.doi.org/10.5539/jfr.v5n2p73

\begin{abstract}
Various levels of bambara groundnut protein cocnentrate ranging from 0 to $15 \%$ were used in the formulation of plantain paste (Amala) and plantain baked products. 'Amala' and cookies were produced from $85 \%$ plantain flour and 15\% bamabara groundnut protein concentrate, while cakes and bread were produced from $70 \%$ wheat flour, $20 \%$ plantain flour and 10\% bambara groundnut protein concentrate. Starch fractions and in vitro starch hydrolysis of the products were determined. The lowest total starch value was found in plantain flour (51.51\%) and highest in cakes $(70.62 \%)$. There was no significant difference in resistant starch between plantain flour and 'amala' (5.22\% and 4.99\%, respectively). The lowest resistant starch was observed in bread (0.94\%), while digestible starch was higher in bread and cakes compared to plantain flour. Higher total starch also resulted in higher digestible starch. The kinetic constant of plantain products showed very low values suggesting generally, higher resistance to enzymatic hydrolysis. The highest hydrolysis index (HI) of 74.85\%, and $74.25 \%$ were observed in cakes and bread, respectively; which also resulted in higher predicted glycemic index (PGI) of $80.79 \%$ (Cakes) and $80.45 \%$ (Bread). These values were significantly different from that obtained for 'amala' with $\mathrm{H} 1$ of $56.40 \%$ with a corresponding PGI of $70.67 \%$ while cookies recorded HI value of $62.64 \%$ and PGI of $74.10 \%$. The lowest HI (53.98\%) and PGI (69.35\%) was observed in plantain flour. This study showed that the more plantain flour in the product formualtions, the lower the hydrolysis index (HI) and the predicted glycemic index (PGI).
\end{abstract}

Keywords: starch hydrolysis, glycemic index, plantain products, bamara groundnut, protein concentrate

\section{Introduction}

In vitro starch hydrolysis has been identified as a simple inexpensive experimental method used in estimating glycemic response of carbohydrate meals (Jenkins et al., 1987; Araya et al., 2002; Dona et al., 2010). These findings helped in reducing the use of human beings and avoiding the complexities associated with human management involved in in vivo experimental designs. Various studies have demonstrated the influence of different nutrients in foods on starch hydrolysis. These nutrients included protein content (Anderson et al., 1981; Chung et al., 2008), moisture content (Lynch et al., 2007), phosphorus content (Noda et al., 2008; Absar et al., 2009) and resistant starch (Frei et al., 2003; Deepa et al., 2010). All these factors had been found to affect starch digestibility. When raw starch granules are gelatinized during heating, the disruption of starch sometimes increases its susceptibility to enzymatic degradation (Holm et al., 1988). In many starchy foods, a portion of residual starch is not fully gelatinized during processing, either due to limited water content or insufficient heating. According to Rashmi and Urooj (2003), such foods include breakfast cereals, flakes and some baked products (cookies, cakes and bread). The post-prandial responses of food containing raw or partially gelatinized starches have become the subject of increasing interest in recent years. Slowly digested carbohydrates are generally considered to be beneficial for the dietary management of metabolic disorders including diabetes and hyperlipidemia (Brand-Miller, 2003; Lehmann \& Robin, 2007).

Different processing conditions affect the gelatinization of starch as measured by the enzymatic method. Englyst et al. (1992) had earlier classified starch based on its digestibility (measured by in vitro enzyme) as rapidly digested starch (RDS), slowly digested starch (SDS) and resistant starch (RS) all based on time of hydrolysis. 
Rapidly digested starch is the starch fraction that causes a rapid increase in blood glucose level after ingestion while slowly digested starch is the starch fraction that is digested slowly but completely in the large intestine (Englyst et al., 1992). The potential health benefits of SDS include stable glucose metabolism, diabetes management, mental performance and satiety (Lehmann \& Robin, 2007). Also, the health benefits of RS have been reported as prevention of colon cancer, hypoglycemic effects, substrate for growth of probiotics, reduction in gall stones formation, hypo-cholesterolemic effect, in-hibition of fat accumulation and increasing absorption of minerals (Sajilata et al., 2006). Long-term intake of low GI foods was reported to associate with the reduced incidence and prevalence of heart diseases, diabetes and also some form of cancer (Brand-Miller, 2007; Jenkins, 2007). Studies have shown that a low GI diet not only improves certain metabolic consequences of insulin resistance but also reduces it. Based on the above, the Food and Agriculture Organisation (1998) expert consultation on dietary carbohydrates strongly advocate the relevance of the GI concept. The therapeutic value of low GI diet in diabetes has been demonstrated in type 1 and type 2 patients (Brand-Miller, 1994).

In Nigeria, plantain (Musa paradisaca) is a popular food commodity and a cheap source of carbohydrate. Important attribute of unripe plantain fruit is its glycemic index (GI) which compares equal quantities of carbohydrates and provides a measure of carbohydrate quality and not quantity (Liu et al., 2000). Unripe plantain has also been reported to contain high slowly digestible total starch with a low glycemic index (GI); high content of resistant starch and dietary fibre (Okafor \& Ugwu, 2013). The international table of glycemic index and load showed that unripe plantain has a glycemic index of $40 \pm 4$. Since low GI foods release glucose at a slower rate compared to high GI foods, plantain flour has the potential to slow down the rate of starch hydrolysis in plantain-based products. This is expected to be useful in the formulation of diets for diabetic and obese individuals. Hence, the objective of this research was to formulate food products such as amala, cakes, cookies and bread from plantain flour enriched with bambara groundnut protein concentrate in order to increase the protein content of the products, to carry out the in vitro starch hydrolysis and prediction of glycemic index on the products.

\section{Materials and Methods}

\subsection{Plantain and Bambara Groundnut Seeds}

A local cultivar (agbagba) of plantain (Musa paradisiaca) was collected from the International Institute for Tropical Agriculture, (IITA) High Rainfall Station; Onne, agro-ecology, located at lat, $04^{\circ} 431 \mathrm{~N}$, long. $07^{\circ} 01$; E and $10 \mathrm{~m}$, near Port Harcourt, Rivers State and used for this study. Bambara groundnut (Vigna subterrenea L. verdc) seeds - (the cream coloured variety) was purchased from markets in Enugu, Enugu State, all in Nigeria. Pepsin (Cat. No P6887, 0.4 units/mg), and $\alpha$-amylase (cat. No A 3176, 16 units $/ \mathrm{mg}$ ) enzymes were purchased from Sigma-Aldrich Chemcials Ltd, U.S.A. Other chemicals include potassium hydroxide, 3-5 dinitrosolicyclic acid, D-glucose, sodium hydroxide and phosphate buffer.

\subsection{Preparation of Bambara Groundnut Flour}

Bambara groundnut flour was prepared using the method described by Barimalaa et al., (1994). The beans were soaked for $24 \mathrm{~h}$ in tap water and dehulled manually. The seeds were further boiled for $10 \mathrm{~min},(1: 4$ bean to water ratio, $w / v$ ) in a stainless steel pot, drained and dried for $19 \mathrm{~h}$ at $50^{\circ} \mathrm{C}$ in an air circulating oven. The dried samples were milled (FOSS, Cyclotec 1093, Sweden) and sieved into flour using $0.25 \mathrm{~mm}$ sieves.

\subsection{Preparation of Protein Concentrates}

The protein concentrates from Bambara groundnut flour (BGFC) were prepared using the alkaline wet extraction process described reported by Giami and Isichei (1999), for fluted pumpkin seeds, and adopted for bambara groundnut protein concentrate as earlier reported by Kiin-Kabari and Giami (2015).

\subsection{Product Formulations}

\subsubsection{Amala}

"Amala" is a common plantain paste produced by stirring plantain flour enriched with $15 \%$ bambara groundnut protein concentrate in hot water $(1: 4, w / v)$ until a smooth paste was formed as reported by Kiin-Karbari et al. (2015).

\subsubsection{Baked Products}

\subsubsection{Cookies}

Circular cookies were produced from $85 \%$ plantain flour and $15 \%$ Bambara groundnut protein concentrate as described by Arisa et al. (2013) with modififcations as reported by Kiin-Kabari and Giami (2015). 


\subsubsection{Bread}

The batter method described by Ogazi (1984) was used with modifications. Bread was produced using 70\% wheat flour, $20 \%$ plantain flour and $10 \%$ bambara groundnut protein concentrate as recommended by Kiin-Kabari et al. (2015). After mixing, the resultant batter was scaled (500g), proofed for $20 \mathrm{~min}$ and baked at $180^{\circ} \mathrm{C}$ for $45 \mathrm{~min}$.

\subsubsection{Cake}

Queen cake was produced from the composite flour (70\% wheat flour, $20 \%$ plantain flour and $10 \%$ bambara groundnut protein concentrate) using the creaming method of blending. Half of the composite flours were mixed with all the fat for 2 min to obtain a creamy dough before the remaining composite flour and other ingredients were added, more water was added gradually and mixing continued until the dough was soft and greasy. The dough was molded, shaped and baked in the oven at $200^{\circ} \mathrm{C}$ for $15 \mathrm{~min}$.

\subsection{Starch Hydrolysis}

\subsubsection{Total Starch}

The total starch in the plantain products (amala, cakes, cookies, bread) developed was determined enzymatically according to the modified method of Goni et al. (1997). The samples were ground to pass through a $0.5 \mathrm{~mm}$ sieve. Subsequently, $25 \mathrm{mg}$ of each sample was dissolved in $6 \mathrm{ml}$ of $2 \mathrm{MKOH}$ and shaken vigorously for $30 \mathrm{~min}$ at room temperature. A stock solution of $\alpha$-amylase was prepared by mixing $20 \mathrm{mg}$ of porcine pancreatic $\alpha$-amylase with $50 \mathrm{ml}$ of $0.2 \mathrm{~m}$ phosphate buffer $(\mathrm{pH} 6.9)$. One $(1 \mathrm{ml})$ of the $\alpha$-amylase solution was added to the sample suspension and incubated at $37^{\circ} \mathrm{C}$ for $45 \mathrm{~min}$ in a shaking water bath. After incubation, $1 \mathrm{ml}$ of $3-5$ dinitrosolicyclic acid was immediately added and the mixture was heated for 5 min to inactivate the enzymes. The solutions after cooling was centrifuged for $10 \mathrm{~min}$ at $3000 \mathrm{xg}$, colour absorption of glucose concentration in the supernatant was determined using a speetrophotometer (Cecil 1021, U.K) at a wavelength of $450 \mathrm{~nm}$. A standard glucose graph $\left(\mathrm{Y}=18.719 \mathrm{x}\right.$ and $\left.\mathrm{R}^{2}=0.9445\right)$ of $0.02 \mathrm{mg} / \mathrm{l}$ to $0.1 \mathrm{mg} / \mathrm{l}$ was also prepared and the glucose concentrations of each sample obtained. The results was converted to starch by multiplying the percentage glucose concentration by a factor 0.9 .

\subsubsection{Resistant Starch (RS)}

This was also determined according to the method of Goni et al. (1997). One hundred (100mg) of each sample (residue from total starch) was incubated with pepsin solution containing $20 \mathrm{mg}$ of pepsin (Cat. No. P6887) for $60 \mathrm{~min}$ at $40^{\circ} \mathrm{C}$ for protein removal. Then the starch was hydrohysed by adding the enzyme solution $40 \mathrm{mg}$ of $\alpha$-amylase and incubated at $37^{\circ} \mathrm{C}$ for $120 \mathrm{~min}$. After hydrolysis, samples were centrifuged and the supernatant discarded. The residue was analysed for starch as described for total starch.

Digestible starch (DS) content was taken to be the difference between the total starch (TS) and the resistant starch (RS) as reported by Frei et al. (2003), Capriles et al. (2008) and Kiin-Kabari and Giami (2015).

\subsection{In-vitro Starch Digestion Rate and Prediction of Glycemic Index (PGI)}

The starch digestion rate for plantain products (amala, cookies, cakes and bread) were expressed as the percentage of total starch hydrolysed over time intervals of $30 \mathrm{~min}, 60 \mathrm{~min}, 90 \mathrm{~min}$ and $120 \mathrm{~min}$ of incubation. The Hydrolysis Index (HI) was derived from the ratio between the areas under the hydrolysis curve of the various products developed and the reference sample (glucose). From the hydrolysis index obtained, the predicted glycemic index (GI) was calculated using the equation established by Goni et al. (1997); PGI $=39.7+0.548 \mathrm{HI}$.

$$
H I=\frac{\text { AUC of product }}{\text { AUC of glucose }} \times 100
$$

Where AUC $=$ Area under the curve

$$
\mathrm{AUC}=C \infty\left(\mathrm{t}_{\mathrm{f}}-\mathrm{to}\right)-(\mathrm{C} \infty / \mathrm{k})(1-\exp )-\mathrm{K}\left(\mathrm{t}_{\mathrm{f}}-\mathrm{to}\right)
$$

Where $t_{\mathrm{f}}=$ Final time, to $=$ Initital time $(\mathrm{min})$.

$C \infty=$ Equilibrium percentage of starch hydrolyzed after 120min, which is the glucose content after 120min divided by the total starch.

The kinetics of starch hydrolysis was calculated using a non-linear equation

$$
\mathrm{C}=\mathrm{C} \infty\left(1-\mathrm{e}^{-\mathrm{kt}}\right),
$$


Where $\mathrm{K}=$ Kinetic constant. $\mathrm{K}$ was derived to be

$$
\mathrm{K}=-\operatorname{In} \frac{(\mathrm{I}-\mathrm{C} / \mathrm{C} \infty)}{\mathrm{t}}
$$

Where $\mathrm{C}=$ Percentage of starch hydrolysed at time t.

\subsection{Statistical Analysis}

Results were expressed as mean values and standard deviation of three (3) determinations. The obtained data were analysed using a one way Analysis of Variance (ANOVA) using Statistical Package for Social Science (SPSS) version 20.0 software 2011 (Soft Inc. Tulsa, USA) to test the level of significance $(\mathrm{p}<0.05)$. Duncan New Multiple range Test was used to separate the means where significant differences existed. Correlation coefficients ( $r$ ) were determined on all standard curves.

\section{Results and Discussion}

\subsection{In-vitro Starch Hydrolysis}

The results for total starch of plantain flour was low (51.51\%), which also indicated a low digestible starch of $46.29 \%$ as shown in Table 1. This resulted in a high resistant starch value of $5.22 \%$. High resistant starch value of $4.99 \%$ was also observed in 'amala'. These values are significantly different from the low resistant starch observed in cakes and bread. This observation may be attributed to the fact that the heat treatment applied in both cases may not be sufficient to fully gelatinize starch granules thus making it resistant for $\alpha$-amylase digestion. This agreed with the work of Oboh and Erema (2010) which showed that processing of unripe plantain meals alters the physical form of the carbohydrates. Unripe plantain had also been reported to have small concentration of free sugars and rapidly digestible starch (Ramdath et al., 2004). Cookies had a resistant starch (RS) of $3.30 \%$ and a digestible starch fraction of $60.23 \%$ which in addiction may be related to the properties of the granules and its physical association with the plant cell wall (fibre), which could contribute to reducing total starch gelatinization. Plantain bread and cakes had the lowest resistant starch values of $0.94 \%$ and $2.95 \%$, respectively which also resulted in higher values for digestible starch of $68.45 \%$ for cakes and $67.40 \%$ for bread. This observation may be due to product formulation and processing method which made the starch granules to gelatinize and more available to enzymatic digestion.

Table 1. Total Starch (TS), Resistant Starch (RS) and Digestible Starch (DS) of plantain products

\begin{tabular}{llll}
\hline Sample & Total starch (\%) & Resistant starch (\%) & Digestible starch (TS - RS) (\%) \\
\hline Plantain flour & $51.51^{\mathrm{c}}$ & $5.22^{\mathrm{a}}$ & $46.29^{\mathrm{c}}$ \\
Amala* $^{\mathrm{b}}$ & $64.33^{\mathrm{b}}$ & $4.99^{\mathrm{a}}$ & $59.34^{\mathrm{b}}$ \\
Cookies* $^{*}$ & $63.53^{\mathrm{b}}$ & $3.30^{\mathrm{b}}$ & $60.23^{\mathrm{b}}$ \\
Bread + & $68.34^{\mathrm{a}}$ & $0.94^{\mathrm{c}}$ & $67.40^{\mathrm{a}}$ \\
Cakes $^{+}$ & $70.62^{\mathrm{a}}$ & $2.95^{\mathrm{b}}$ & $68.45^{\mathrm{a}}$ \\
\hline
\end{tabular}

a,b,c Means bearing the same superscript within the same column do not differ significantly $(\mathrm{p}<0.05)$.

Key:

$*=85 \%$ plantain flour and $15 \%$ Bambara groundnut protein concentrate.

$+=70 \%$ wheat flour, $20 \%$ plantain flour and $10 \%$ Bambara groundnut protein concentrate. 


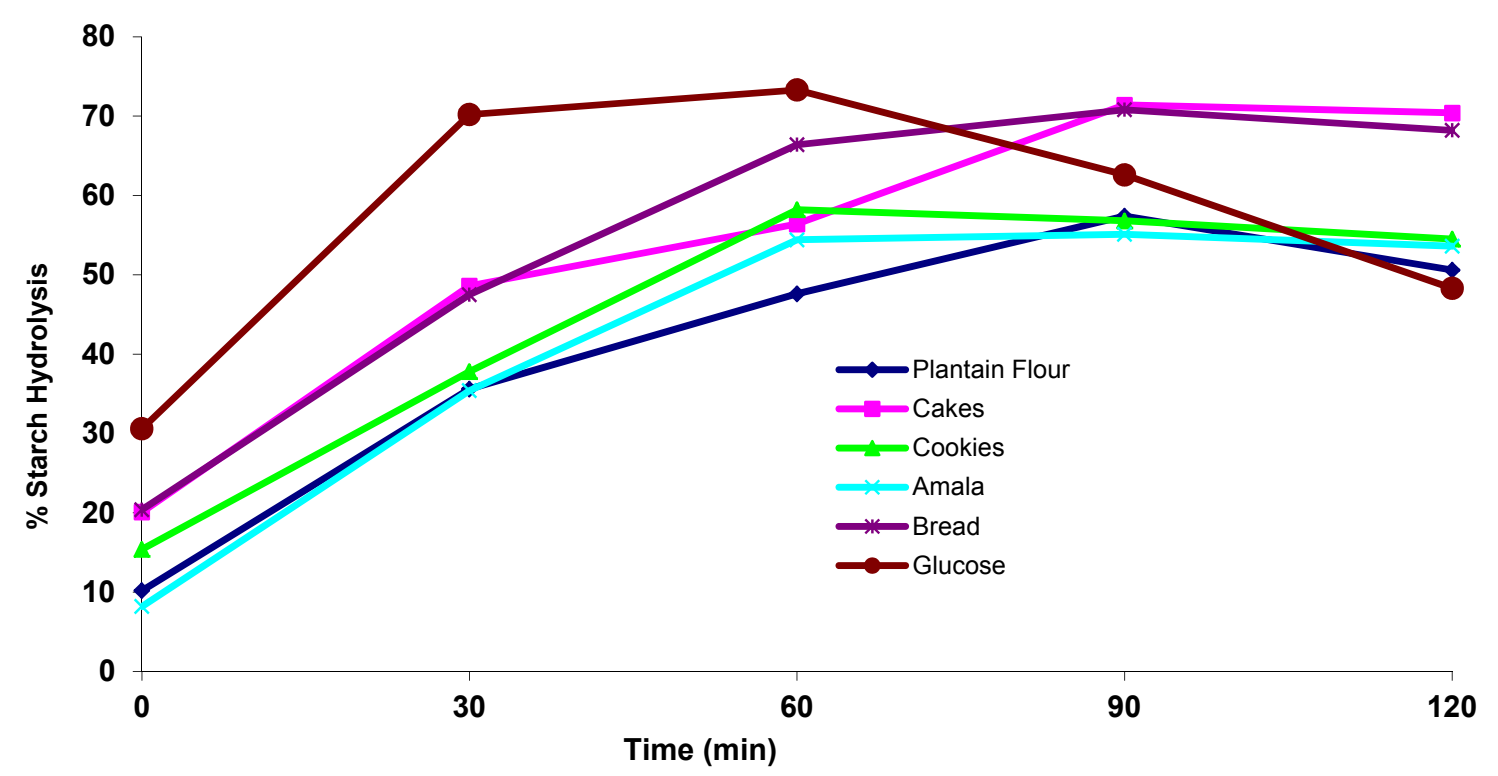

Figure 1. Rate of starch hydrolysis of plantain product

Key: Amala and Cookies $=85 \%$ plantain flour and $15 \%$ Bambara groundnut protein concentrate

Bread and Cake $=70 \%$ wheat flour, $20 \%$ plantain flour and $10 \%$ Bambara groundnut protein concentrate.

\subsection{Equilibrium Concentration (C), Kinetic Constant (K), Hydrolysis Index (HI) and Predicted Glycemic Index (PGI) of Plantain Products}

The equilibrium concentration (C) was higher in cakes $(71.4 \%)$ and bread $(70.8 \%)$ which indicated no significant difference $(\mathrm{p}<0.05)$ as presented in Table 2 . However, when related to the rate of hydrolysis over time as shown in Figure 1. These plateaux were reached at $90 \mathrm{~min}$ compared to glucose that attained its peak at $78.4 \% \mathrm{w}$-ithin $60 \mathrm{~min}$. Kinetic constant $(\mathrm{K})$ of the various plantain products showed very low values between 0.0274 (amala) to 0.038 for bread and 0.028 for cake. These low values suggest generally higher resistance to enzymatic hydrolysis. This is in agreement with the report of Jaisut et al. (2009) that observed direct influence of both $\mathrm{K}$ and $\mathrm{C}$ parameters on the starch hydrolysis of brown rice.

The highest hydrolysis index (HI) of $74.85 \%$ were observed in cakes and $74.25 \%$ in bread which resulted in higher predicted glycemic index (PGI) of $80.79 \%$ for cakes and $80.45 \%$ for bread The values were significantly different from that obtained for 'amala' with HI of $56.40 \%$, PGI $70.67 \%$ and cookies with HI value of $62.64 \%$ and PGI of $74.10 \%$. The lowest HI (53.98\%) and PG1 (69.35\%) was recorded in plantain flour. The result showed that the more plantain flour in the product formulations, the lower the HI which subsequently led to the reduced predicted glycemic index (PGI). This may be that plantain contains carbohydrates whose bulk may consist of non-starch polysaccharides with a low GI. Studies have shown that a low GI diet not only improves certain metabolic consequence of insulin resistance but also reduces insulin resistances Perse (Del-Prato et al., 1994). In addition to improvement in glucose and lipid metabolism, there are indications of improvements in fibrinolytic activity suggesting beneficial roles in the management of diabetes and cardiovascular diseases (Brand-Miller et al., 1991; Jarvi et al., 1999). However, Oboh and Erema (2010) reported a glycemic index of plantain flour to be $65.05 \%$ which is lower than $69.35 \%$ recorded in this study. This difference may be attributed to factors such as processing methods, product compositions such as proteins (Mander et al., 2005) and fat (Collier et al., 1984). Although, predicted glycemic index for white bread had been reported to be $94.61 \%$ (Capriles et al., 2008) compared to $80.45 \%$ obtained for composite plantain bread in the study. Again, this difference may probably be due to the inclusion of plantain flour and protein concentrates in the formulation of the bread. Although, the addition of bambara groundnut protein concentrate did not affect enzymatic hydrolysis, it may contribute to the functionality of the baked products. 
Table 2. Equilibrium Concentration (C), Kinetic Constant (K), Hydrolysis Index (HI) and Predicted Glycemic Index (PGI) of Plantain Products

\begin{tabular}{lllll}
\hline Sample & $\begin{array}{l}\text { Equilibrium concentration } \\
(\%)\end{array}$ & $\begin{array}{l}\text { Kinetic constant } \\
(\mathrm{K})\end{array}$ & $\begin{array}{l}\text { Hydrolysis index } \\
(\mathrm{HI})\end{array}$ & $\begin{array}{l}\text { Predicted glycemic index } \\
(\%)\end{array}$ \\
\hline Cakes + & $71.4^{\mathrm{b}}$ & $0.028^{\mathrm{a}}$ & $74.85^{\mathrm{a}}$ & $80.79^{\mathrm{a}}$ \\
Cookies * & $66.8^{\mathrm{b}}$ & $0.025^{\mathrm{a}}$ & $62.64^{\mathrm{c}}$ & $74.10^{\mathrm{c}}$ \\
Amala * & $58.1^{\mathrm{c}}$ & $0.024^{\mathrm{b}}$ & $56.40^{\mathrm{bc}}$ & $70.67^{\mathrm{b}}$ \\
Plantain & $53.4^{\mathrm{d}}$ & $0.028^{\mathrm{a}}$ & $53.98^{\mathrm{d}}$ & $69 / 35^{\mathrm{c}}$ \\
flour & & & & \\
Bread + & $70.8^{\mathrm{b}}$ & $0.038^{\mathrm{a}}$ & $74.25^{\mathrm{a}}$ & $80.45^{\mathrm{a}}$ \\
Glucose & $78.4^{\mathrm{a}}$ & $0.023^{\mathrm{b}}$ & - & - \\
\hline
\end{tabular}

${ }_{\mathrm{a}, \mathrm{b}, \mathrm{c}, \mathrm{d}}$ Means bearing the same superscript within the same column do not differ significantly $(\mathrm{p}<0.05)$.

Key:

$+=70 \%$ wheat flour, $20 \%$ plantain flour and $10 \%$ Bambara groundnut protein concentrate.

$*=85 \%$ plantain flourand and $15 \%$ Bambara groundnut protein concentration.

\section{Conclusion}

The results showed that plantain flour and 'amala' contained high values of resistant starch or slowly digestible starch. The addition of plantain flour in the baked products lowered the hydrolysis index and the corresponding predicted glycemic index. The low starch digestibility values of $60.23 \%$ and $59.34 \%$ for plantain cookies and amala are an indication that these products may be useful as functional food for diabetic and obese individuals.

\section{References}

Absar, N., Zaidu, I. S. M, Takigawa, S., Hashimoto, N., Matsuura-Endo, C., Yamauchi, H., \& Noda, I. (2009). Enzymatic hydrolysis of potato starches containing different amounts of phosphorous. Food Chemical, 122, 57-62. http://dx.doi.org/10.1016/j.foodchem.2008.05.045

Anderson, L. H., Lavine, A. S., \& Levitt, M. D. (1981). Incomplete absorption of carbohydrate in all purpose wheat flour. New England Journal of Medicine, 304, 891-892. http://dx.doi.org/10.1056/NEJM198104093041507

Araya, H., Contreras, P., Alvina, M., Vera, G., \& Pak, N. (2002). A comparison between an in-vitro method to determine carbohydrate digestion rate arid glycemic response in Youngmen. European Journal of Clinical Nutrition, 56, 735-739. http://dx.doi.org/10.1038/sj.ejen.1601386

Arisa, N. N., Adelakan, A. O., Alamu, A. E., \& Ogunfowora, E. J. (2013). The effect of pretreatment of plantain (Musa paradisiaca) flour on the pasting and sensory characteristics of biscuit. International Journal of Food and Nutrition Science, 2(1), 10-23.

Brand-Miller, J. C. (2003). Glycemic load and chronic diseases. Nutrition Reverence, 61, 6995-7055. http://dx.doi.org/10.1301/nr.2003.may.s49-s55

Brand-Miller, J. C. (2007). The glycemic index as a measure of health and nutritional quality: An Australian perspective. Cereal Food World, 52, 41-44. http://dx.doi.org/10.1094/cfw-52-2-0041

Brand-Miller, J. C., Cologion, S., Crossman, S., Allen, A., Roberts, D., \& Truswell, S. (1991). Low-glycemic index foods improve long-term glycemic control in NTDDM. Diabetes Case, 14, 95-101. http://dx.doi.org/10.2337/diacare.14.2.95

Brand-Miller, J. C. (1994). Important of glycemic index in diabetes. American Journal of Clinical Nutrition, 59, $7475-7525$.

Capriles, V. D., Coelho, K. D., Guerra-Matias, A. C., \& Areas, J. A. G. (2008). Effect of processing methods on Amaranth starch digestibility and predicted glycemic index. Journal of Food Science, 73(7), H160-H164. http://dx.doi.org/10.1111/j.1750-3841.2008.00869.x

Chung, H. J., Lin, Q., Hoover, R., Warkentin, T. D., \& Vandenberg, B. (2008). In-vitro starch digestibility, expected glycemic index and thermal and pasting properties of flours from pea, lentil and chickpea cultivars. 
Food Chemistry, 111, 316-321. http://dx.doi.org/10.1016/j.foodchem.2008.03.062

Collier, G., McLean, A., \& O’Dea, K. (1984). Effect of co-ingestion of fat on the metabolic responses to slowly and rapidly absorbed carbohydrate. Diabetologia Croatiea, 26, 50-54. http://dx.doi.org/10.1007/bf00252263

Deepa, G., Singh, V., \& Naidu, K. A. (2010). A comparative study on starch digestibility, glycemic and resistant starch of pigmented ('Njavara' and Jyothi) and non-pigmented ('JR 64') rice varieties. Journal of Food Science and Technology, 47(6), 644-649. http://dx.doi.org/10.1007/s13197-010-0106-1

Del-Prato, S., Leonctti, F., Simonson, D. C., Sheehan, P., Matsuda, M., \& Defronzo, R. A. (1994). Effect of sustained physiologic hyperinsulinemia and hypergly caemia on insulin secretion and insulin sensitivity in man. Diabetologia, 37, 1025-1035. http://dx.doi.org/10.1007/BF00400466

Dona, A. C., Pages, G., Gilbert, R. G., \& Kuchel, P. W. (2010). Digestion of starch: Invivo and Invitro kinetic models used to characterize oligosaccharides of glucose release-Review. Carbohydrate Polymers, 80, 599-617. http://dx.doi.org/10.1016/j.carbpol.2010.01.002

Englyst, H. N., Kingmans, S. M., \& Gummings, J. H. (1992). Classification and measurement of nutritionally important starch fraction. European Journal of Clinical Nutrition, 46(2), 335-505.

FAO/WHO. (1998). Carbohydrates in human nutrition report of a joint/FAO/WHO experts consultation. Rome.

Frei, M., Siddhuraju, P., \& Becker, K. (2003). Studies on the in-vitro starch digestibility and the giycemic index of six ditterent indigenous rice cultivars from Philippines. Food Chemsitry, 83(3), 395-402. http://dx.doi.org/10.1016/S0308-8146(03)00101-8

Goni, I., Garci-Alonso, A., \& Suara-Calirto, B. (1997). Starch hydrolysis procedure to estimate glycemic index. Nutrition Research, 17, 427-437. http://dx.doi.org/10.1016/S0271-5317(97)00010-9

Holm, J., Lundquist, I., \& Biórck, I. (1988). Degree of starch gelatinization, digestion rate of starch in vitro and metabolic response in rats. American Journal of Clinical Nutrition, 47, 1010-1016.

Jaisut, D., Prachayawarkorn, S., Varanyanond, W., Tungtyrakul, P., \& Soponronnarit, S. (2009). Accelerated aging of jasmine brown rice by high-temperature fluidization technique. Food Research International, 42(5-6), 674-681. http://dx.doi.org/10.1016/j.foodres.2009.02.011

Jarvi, A. E., karistrom, B. E., Granfeldt, Y. E., Bjorckl, K. E., Asp, N. G., \& Vessby, B. O. H. (1999). Improved glycemic control and lipid profile and normalized fibrinolytic activity on a low-glycemic index diet in type 2 diabetic patients. Diabetes Case, 22, 10-18. http://dx.doi.org/10.2337/diacare.22.1.10

Jenkins, D. J. A., Thorne, M. J., Wolever, T. M. S., Jenkins, A. L., Venketschuter, R., \& Thompson, L. U. (1987). The effect of starch protein interaction in wheat on glycemic response and rate of in vitro digestion. American Journal of Clinical Nutrition, 45, 946-951.

Jenkins, A. L. (2007). The glycemic index: Looking back 25 years. Cereal Foods World, 52, 50-53. http://dx.doi.org/10.1094/cfw-52-1-0050

Kiin-Kabari, D. B., Giami, S. Y., \& Boisa, N. (2015). Bioavailability of minerals in plantain based products enriched with bambara groundnut protein concentrate. Journal of Food Research, 4(4), 74-80. http://dx.doi.org/10.5539/jfr.v4n4p74

Kiin-Kabari, D. B., \& Giami, S. Y. (2015) physico-chemical, starch fractions and dietary fibre of Biscuits produced from different levels of substitution of wheat flour with pantain flour. International Journal of Food Science and Nutrition Engineering, 5(5), 197-202. http://dx.doi.org/10.5923fj.20150505.03

Lehman, U., \& Robin, F. (2007). Slowly digestible starch - its structure and health implications, A Review. Trends in Food Science and Technology, 18, 346-355. http://dx.doi.org/10.1016/j.tifs.2007.02.009

Liu, S., Whilleft, W., Stampfer, M. H. U. F., Franz, M., Sampson, L., Hennekens, C., \& Manson, J. (2000). A prospective study of dietary glycemic load, carbohydrate intake and risk of coronary heart disease in US women. American Journal of Clinical Nutrition, 71, 1455-1461.

Lynch, D., Liu, Q., Tarn, T., Bizimungu, B., Chen, Q., Harris, P., Chik, C., \& Skjodt, N. (2007). Glycemic index - A review and implications for potato industry. American Journal of Potato Research, 84, 179-190. http://dx.doi.org/10.1007/BF02987141

Manders, R. T., Wagenmakers, A. J., Koopman, R., Rorenc, A. H., Menheere, P. P., Schaper, N. C., ... Van-Loon, L. J. (2005). Co-ingestion of a protein hydrolysate and amino acid mixture with carbohydrate improves plasma glucose disposal in patients with type 2 diabetes. American Journal of Clinical Nutrition, 82(1), 
76-83.

Noda, T., Takigawa, S., Matsura-Edo, C., Suzuki, T., Hashimoto, N., Kottearachi, N. S., ... Zaidul, I. S. M. (2008). Factors affecting the digestibility of raw and gelatinized potato starches. Food Chemistry, 110, 465-470. http://dx.doi.org/10.1016/j.foodchem.2008.02.027

Oboh, H. A., \& Erenna, I. G. (2010). Glycemic indices of procesd ipi p'antain (Musa paradisiaca) meals. African Journal of Food Science, 4(8), 514-521.

Okafor, C. C., \& Ugwu, E. E. (2013). Comparative study of pasting properties of high fibre plantain based flour intended for diabetic food (fufu). Work Academic of Science Engineering and Technology, 497.

Ramdath, D. D., Isaacs, R. L. C., Teclucksingh, S., \& Wolever, T. M. S. (2004). Glycermc index of selected staples commonly eaten in the Cerribean and the effects of boiling V. crushing. British Journal, L 971-977.

RasbmI, S., \& Urooj, A. (2003). Effect of processing on nutritionally important starch fractions in rice varieties. International Journal of Food Science Nutrition, 54, 27-36. http://dx.doi.org/10.1080/096374803161976

Sajilata, M. G., Siigbal, R. S., \& Kulkarmi, P. R. (2006). Resistant starch-A review. Food Science and Food Safety, 5, 1-17.

\section{Copyrights}

Copyright for this article is retained by the author(s), with first publication rights granted to the journal.

This is an open-access article distributed under the terms and conditions of the Creative Commons Attribution license (http://creativecommons.org/licenses/by/3.0/). 